\title{
COASTAL ENGINEERING
}

\section{Chapter 7}

\section{SALIIIIY PROELERTS}

H. B. Simmons

Chief, tstuaries Section, Waterways ixperiment Station, Corps of tingineers, Vicksburg, Mississippi

\section{INIFONUCTIUN}

The basic sources of salt-water pollution ase the ocean, induscry, and the soil. 'ilue ocean is responsiole for tne intrusion of salt water into rivers, canals, and lakes, and for infiltration of sea water into aquifiers which are tapped oy wells. Industry causes salt-water pollution by aischar ing the brine of miries, oil wells, tanueries, and other industrial wastes into rivers and lakes. I'he soil is a source of salt-water pollution beciuse of une mun-off from chloride-bearing soils anc tine solution of soluble rocks. The most coninnon and inportant source of salt-water pollution is t.le ocean, and is the only source considered in tinis paper.

\section{NAIURL UF SALIVIIYY PROBLWWS}

l'he types of salinity problems encountered are too numerous to permit covercge in i single paper; however, the most iuportant are those perteinung to pollution of municipal, industrial, and irrigation water supplies, and to shoaling of navigation channels and harbors because of precipitation of suspended or dissolved solids which would otherwise pass out to sea. The subsequent parts of this paper define the above problems in more detail, describes methods which have been proposed or adopted for the solution of similar problems, and describes certain hycaralic model investigations of salinity problems. A selected bibliograpny is included which presents references to the most important literature available to the writer. References listed in the oibliography can be obtained on loan from the kesearch Center Library, Waterways ixperiment Stã Ion, Vicksburg, Wississippi.

\section{Pollution of water supplies}

Salt water does not constitute a healtn hazard, but its taste in arinking water is very objectionable. I'ne USPH "Treasury Standard" therefore linits the amount of cinlorides to 250 parts per million, which is the approxinate concentration at which consumers will begin to complair of salty taste. Hany industries require water of very low salinity, the maximum allowable in certain products being 10 to 15 parts per million of chilorides.

Proolems relative to pollution of irrigation water supplies are generally sinilar to those of municipal and industrial supplies; however, the demand for irrigation wat $\in$ r and the toleraole lumits of salinity vary with the season of the year and the crops to be irrigated. The results of a study of the Pecos kiver Basin by the National Resources Planning Board indicated that: (a) for salinities up to 3000 parts per 


\section{SALINITY PROBLEMS}

million total salts little injury to crops was evident; (b) between 3000 and $600 \mathrm{u}$ parts per million growth was linited to salt-tolerant crops; (c) between 6000 and 10,000 parts per million salt-tolerant crops will grow but seldorn thrive well; and (d) above 10,000 parts per miliion plant growth was limited to some grasses and shrubs. ${ }^{*}$

The results of a study made by the Louisiana State Department of Conservation to determine tolerable linits of salinity in irrigation water for rice indicate that the allowable li.it ranged from 560 to 2900 parts per million total salts, de sending upon the stage of growth of the crops.2 In the Sacramento-San Joaquin Delta in California, the tolerable limit was established as approximately 330 parts per million chlorides. Crops irrigated in this area consist primarily of asparagus, potatoes, sugar-beets, corn, beans, and other truck crops, and considerable acreage in fruit orchards. It is therefore evident that a tolerable linit of salinity for all irrigation supplies can not be estaolished. lhe crop to be irrigated, the characteristics of the soil, the amount of irrigation water necessary, and the stage of growth of the crop all affect the salluity that may pe used without harmful effects. Only a tnorough stuay of local conditions, and experinental deternination of allowable linits of salinity for all stages of growth of the crop to be irrigated, will indicate whether or not the water available is suitaole for irrigation purposes.

\section{Shoaling in rivers and harbors}

A large part of the silt carried by some rivers is in the form of collodial or semi-collodial suspension or in solution. An important property of these particles of solids is that they exhibit no tendency to ball together and forn deposits on the river beds, for the reason that each particle is charged with a negative electric potential. This potential being the same in all paricles, the latter repel each other and a complete state of dispersion prevails so long as the water is fresh. Contact with salt water, however, causes a base-excrange reaction, whereby the eleciric potential is neutralized and a process of clotilng, technically innown as coagulation or flocculation, results. At first the flocs or lumps of coagulated material are quite small; however, as more and more particles are attached the lumps attain sufficient size and weight to sink to the bottom, thus effecting deposits on the river beds. Shoaling frorn this source appears to be most werious in the tidal sections of rivers dralning from the Appalachian Nountains and discharging into the itlantic Ocean and the eastern portion of the Gulf of Wexico.3

\section{MANIER OF SALINIIYY INIRUSIUN}

Intrusion of salt water from the ocean may occur as flow through open channels or by Infiltration into ground water supplies. In many coastal areas the source of municipal ana other water supplies consists of wells. In some cases such wells have been driven inaiscrininately, and are being pumped at a rate greater than that at which the acyuifier

\footnotetext{
* See references at end of chapter
} 


\section{COASTAL ENGINEERING}

is being replinished with fresh water. Under these conditiors salt water may be drawn into the water-bearing strata and cause contamination of the entire supply. Occasionally, the ground water supplies of coastal areas may become polluted because of surface flooding by sea water. Many wells in New Éngland were contaminated in this manner as a result of the 1943 hurricane; however, the contamination was only temporary, and continued pumping of the wells soon reduced their salinities to normal levels. 4

The upstream movernent of salt water in open channels is attrioutable to the greater density of salt water as compared to that of fresh water. l'he nature and extent of such intrusion in a specific channel is dependent upon the range of tide and salinity of the sea water at the mouth of the estuary, the physical and hydraulic characteristics of the estuary proper, and the volume of fresh water being discharged into the estuary from the fresh-water seciion upstream. 'l'he manner of intrusion may vary from the well-defined wedge which is typical of the lower Mississippl river to the salisity front whych may be found in San Francisco Bay and Delaware baj and Rlver; likewise, any modificarion petween these two extrenes is possible if the proper physical and hydraulic conditions exist in an estuary.

The well-defined sali-water wedge, such as exisis in the lower Wississippi Kiver, is illustratea by Fig. 1 . ' the range of tide at the moutn of the liississippi tuver is so small that there is no reversal of flow in the river because of tidal action; therefore, the position of the wedge is governed almost entirely by the volume of fresh water flow. Flow withyn the salt-water wedge is always upstream because of its greater density, while flow in the fresh or semi-fresh water stratas above is always downstream. The interface between the salt and fresh water is fairly well defined, and along this interface the fresh water continually erodes the salt wedge. The amount of such erosion upstream from a Eiven point is always equal to the upstream discharge of salt water at that point so lon: as the position of the wedge remains stable, or until the fresh wacer discharge changes. If the fresh-water flow decreases, the weace slowly moves upstream; conversely, if the freshwater flow increases, the wedge is forced downstream to a new position. is an example of the magnitude of intrusion in the lower liississippi River, salt water is found 135 miles upstream from the mouth (entrance to Southwest Pass) following prolonged periods of low river discharge. On the other hand, the wedge is pushed entirely out of the river during periods of extremely high river discharge.

Salinity intrusion in Delaware and San Francisco Bays appears to be in the form of a salinity front rather than a salt-water wedge, and is illustrated by Fig. 2. Salinities decrease progressively as distance frou the ocean increases, and there is but little difference vetween surface and bottom salinity at any given point in the estuary. The salunity front advances ana retreats with both tidal fluctuation 


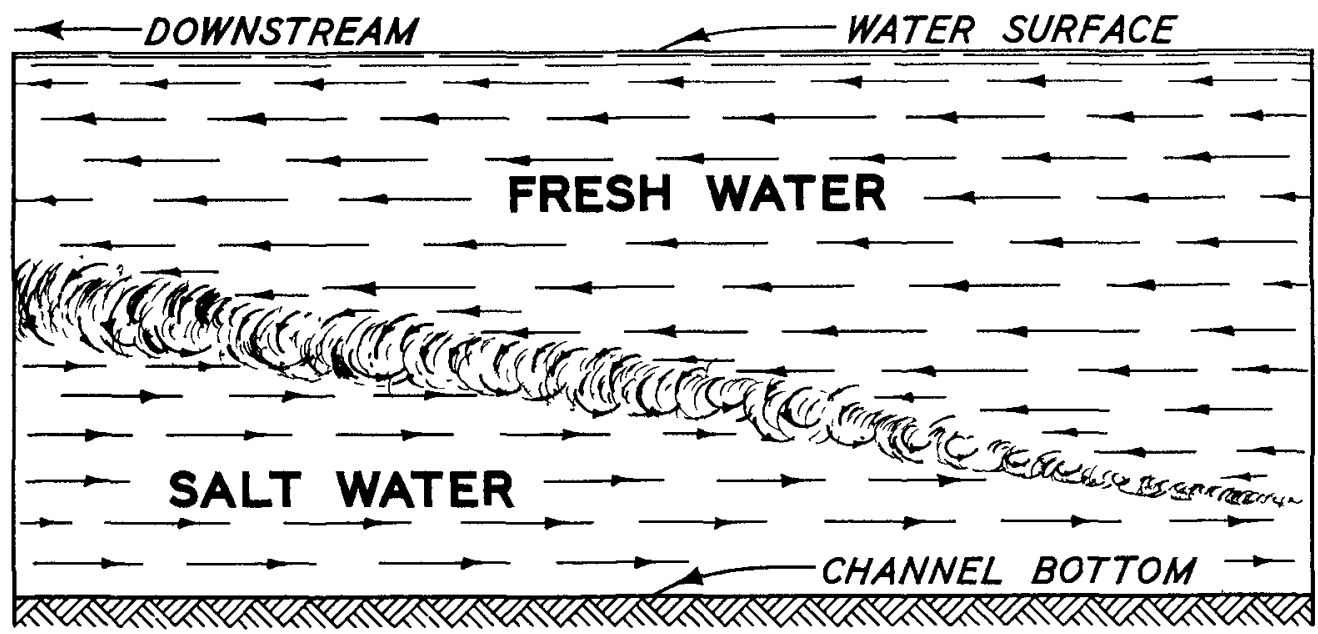

Fig. 1. This shows schematically the distribution of flow in an estuary having a well defined salt-water wedge (similar to lower Mississippl River). Flow in the wedge is always upstream, and flow in the fresh-water strata is always downstream. The thickness of the interfacial layer varies with the fresh-water discharge.

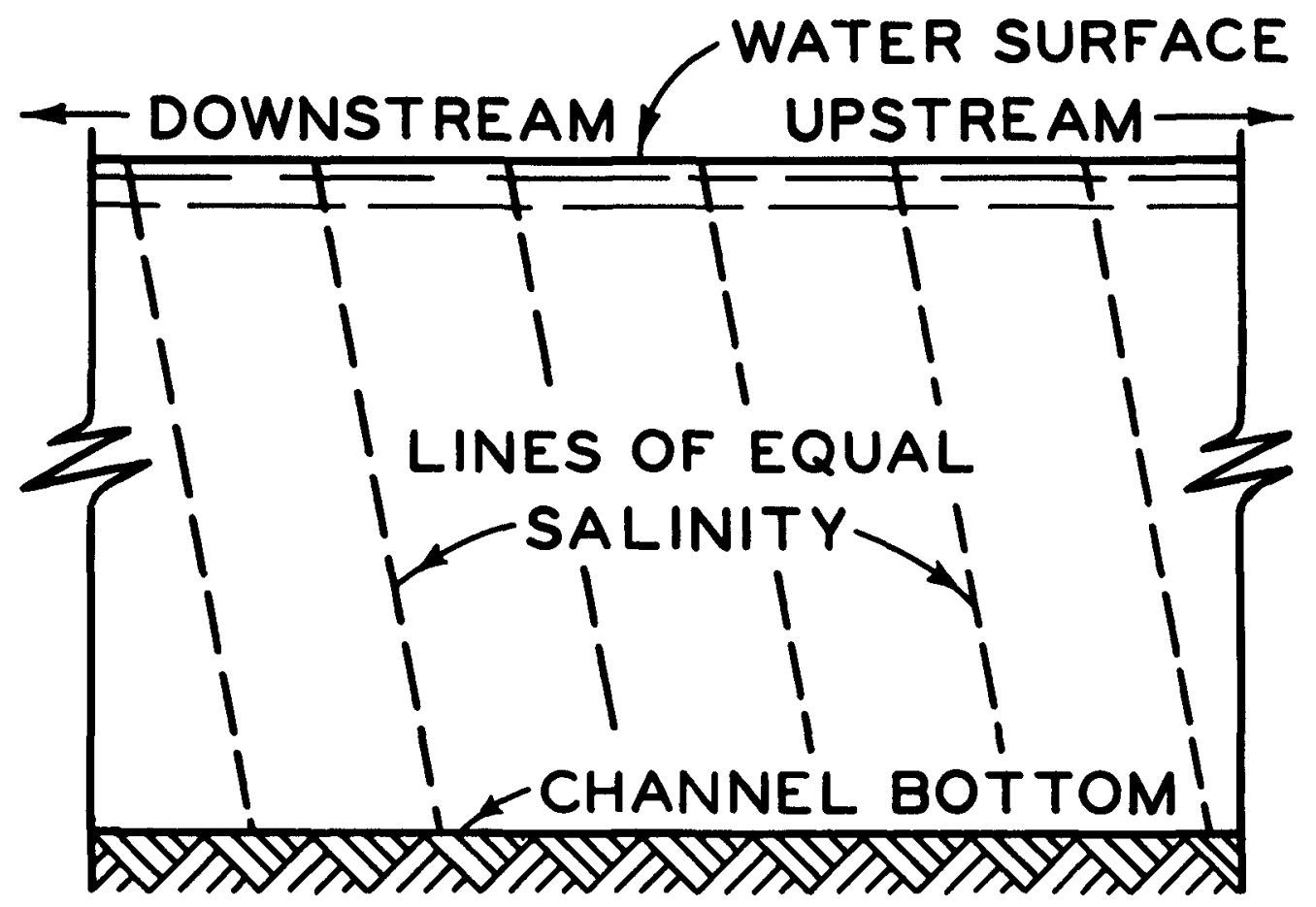

Fig. 2. This shows schematically the distribution of salinity in an estuary in which mixing caused by tidal turbulence does not permit formation of a well defined salt-water wodge (similar to San Francisco and Delaware Bays). The salt-water front advances and retreats with tidal action, but there is little difference in salinity from surface to bottom. 


\section{COASTAL ENGINEERING}

and change in fresh-water discharge, but the relation between surface and botiom salinity at all points in the estuary does not change appreciaily.

Salinity intrusion in the Savannah Kiver, Georgia, and the Cooper Iiver in South Carolina might be classified as falling betweon the two extremes descrioed avove and is illustrated by Fif. 3. There is a definite salt-water wedge in these latter rivers; however, the direction of flow within the wedge reverses wilh change in direction of the tidal currents, and the transition layer between the salt water and fresh water is much thicker than that found in the lower lississippi iliver. The advance and retreat of the salt-water wedce with tidal fluctuation in the Savannah and Cooper Kivers covers appreciable distances, and the upstream penetration of the wedge varies with the volume of fresh water being discharged into the estuary. 'lhe shape of the wed $\mathrm{E}$ e at high-water slack, or at maxiuun penetration because of tidal fluctuation, is somewhat differeni fron tnat at low-water slack, the wedge having an appreciably steeper front and a lesser range of salinity distribution from surface to botton than is found at low-water slack.

It Is the opinion of the writer that the different types of salinity intrusion descrived anove can be attributed to the prysical and hrdraulic characteristıcs of the estuaries involved. 'line lower wississippi tiver occuries a chanrel which is relatively narrow as compared to ciepth, there is but lictle tidal ringe at the mouth of the river, and the freshwater discharee is relatively lim $e$ es compared to tidal discharge. un the other heil:, whe deep-water channels of Delaware and San Francisco ways are relauively narrow as compared to the total width of the estuaries (or tine estuaries are relatively wide as compared to deptin), the ranges of tide at the nouths of these estuaries are sufficient to produce reversals of flow with accompanying tidal currents of appreciable magnitude, and the fresh-water inflows are quite small as compared to tidal discharges. Faysical and hydriulic conditions in these latter estuaries therefore contribute to the aixing of the salt and fresh waters, and since most of the fresh water enters the estuary at the upstream end, the salinity front type of intrusion exists rather than the wedge type. Conditions in the lower lississippi River are such that but little mixing of the salt and fresh water takes place, and therefore salinity intrusion is in the form of a well-defıned wedge. I'he other two rivers described, the Savannah and the Cooper, are similar in some respects to the lower Mississippi River and in other respects to Deleware and San Francisco Bays; therefore, the type of salinity intrusion in the Savannah and Cooper hiver have some of the characteristics of the former and some of the latter. The channels of the Savannah and Cooper Rivers are relatively narrow as compared to depth, the volumes of fresh water discharged into these estuaries are small as compared to tidal discharges, but the tidal ranges and accompanying tidal currents are sufficiently great to produce considerable mixing of the salt and fresh water. It is 


\section{SALINITY PROBLEMS}
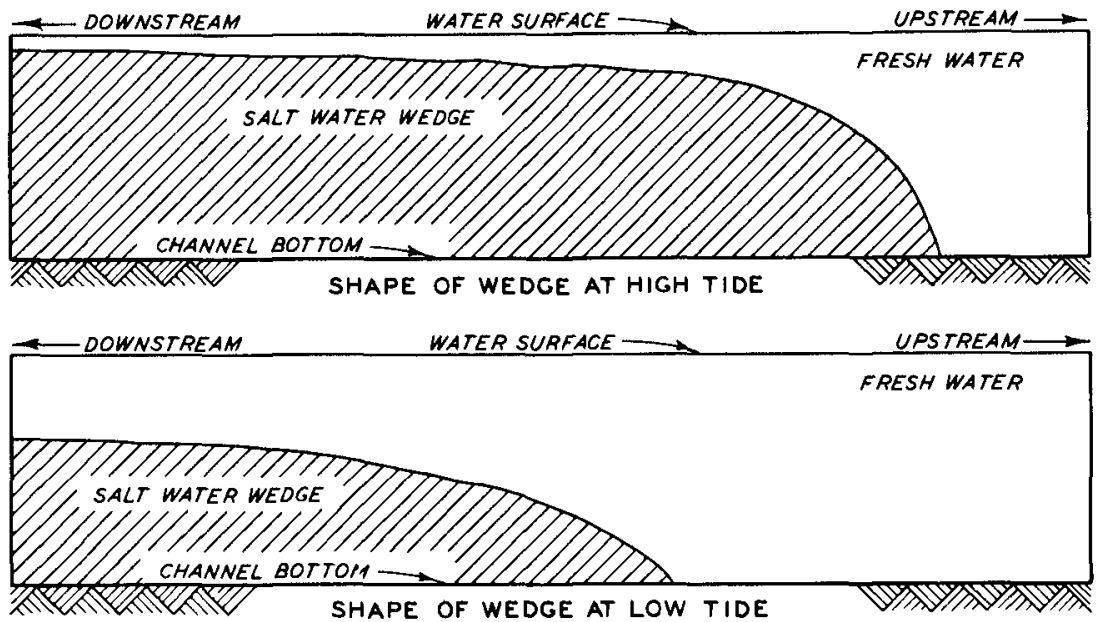

Fig. 3. This shows schematically the effect of tidal action on the salt-water wedge in an estuary having a well defined wedge but also having a sufficient tidal range to cause an appreoiable advance and retreat of the wodge with tidal action (similar to the Savannah and Cooper Rivers). The wedge moves back and forth for considerable distances with tidal action, and the upstream face of the wedge is much steeper at high-water slack than at low-water slack.
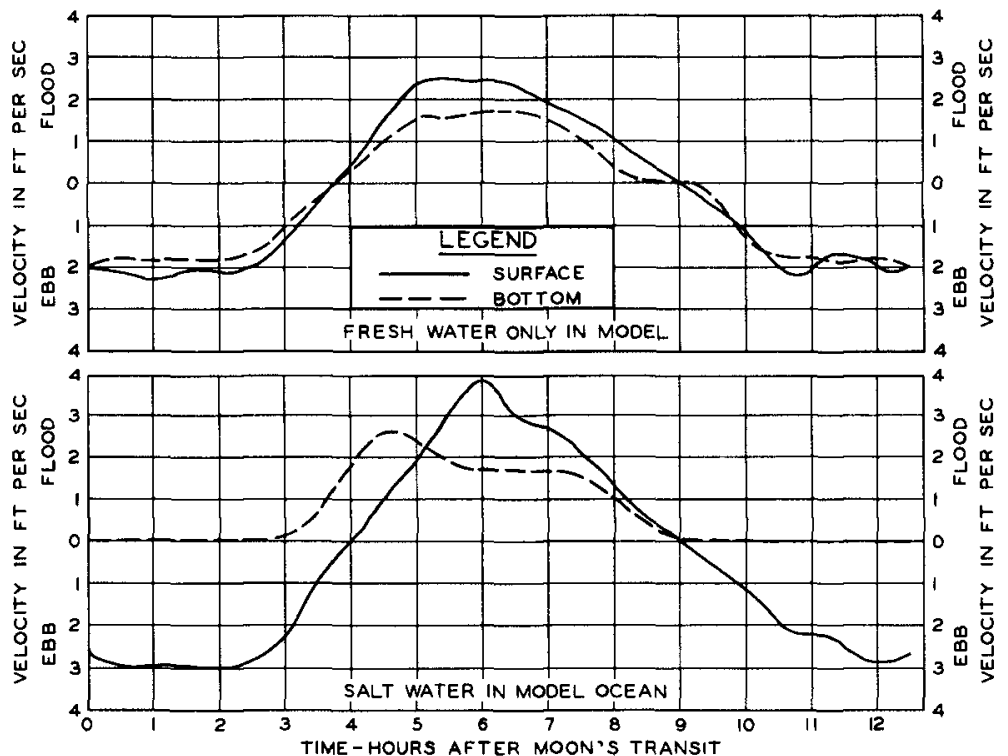

Fig. 4. This shows the effect on current velocities caused by using salt water in the ocean portion of the Savannah Harbor model. The upper plot consists of measurements made with only fresh water in the model, and the lower plot consists of measurements at the same station with salt water in the model ocean. The lower plot is similar to measurements made in the prototype for similar conditions of tide and fresh water discharge. 


\section{COASTAL ENGINEERING}

therefore the opinion of the writer that while the greater density of the salt water as compared to that of the fresn is the basic cause of salinity untrusion in all open chanrels, the type of intrusion to be found in a jiven channel is so modified by local physical and hydraulic conditions trat but little similarity exists between salinity intrusion in any two estuaries. Salinity intrusion in each estuary should be considered and stuaied as an individual problem, and the reasonirg applied with success to one estuary will probably fail completely when applied to another.

\section{CUNTELL OF SALINIIY INTRUSIOIN}

It has been jolnued out that most salinity probiems are unique in nature which woula therefore require that each such problem be studied individually. For this reason it is believed that no set rules or methods for the solution of sali.ity problems cian be developed. Experience and sound judgement on the pert of the engineer concerned with a specific froblem are required to determine the exact nature of the problem, what factors are of greatest significance, and what solutions are feaszble and economical. Some of the attempts that have been made to remedy saltwater problems, and some of the proposals that have been made but have not yet been attempted, are described below.

\section{LOCKS AND GUAKD LOCKS}

Locks are usually constructea to facilitate navigation by making it possiole to transfer a shyp from one level to another. However, in the transit of a ship from a oody of salt water to a body of fresh water, or in the opposite direction, salt water passing through the locks during a ship transit can cause pollution of the fresh water body. It is sometimes desirable, therefore, lo design and construct the lock in such a manner that its chambers may be flushed with fresh water before the gates separating tne lock chambers and tne fresn-water pool are opened. 'this process reduces the salinily of the water in trie lock chanber, thus reducing tue source of poliution to the body of fresn water. l'his method has betn used with success in operation of the locks of the Lake washington Ship Conal, Seattle, washington, 5 and has been proposed for the solution of sinzlar problems in otner locitions, notable of which is the proposed kew Jersey Sni Canal. The design of such locks usually incorporates a aeep sump adjacent to the entrance of the lock into the fresn water pool, the purpose of which is to collect, by virtue of its greater density, the salt water inai succeeds in passing through the locks in spite of all precautions. A slphon located in the botlom of this sump returns the salt water collected therein to the salt water pool below the locks. This method can be made quite effective if a sufticient quantity of fresh water for flushirg the locks is available. 


\section{SALINITY PROBLEMS}

Guard locks are usually constructed to prevent free flow through an open channel, and for this reason they provide an excellent means for preventing the movement of density currents. The use of guard locks, however, is usually linited to waterways in which flow is principally tidal, since, in the case of a waterway having an appreciable fresh water run off, the lock would impede drainage of flood waters. Notable examples of existing guard locks are the Great Bridge Lock in the Atlantic Intracoastal waterway about 12 miles south of lorfolk, Virginla, 7 and the Calcasieu and Viermentau Salt-water Guard Locks in the Gulf Intracoastal water, ay in southwestern Louisiana. 8

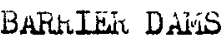

A large number of barrier dams have been proposed for the control of salinity antrusion; however, only a few such siructures have actually been bullt. varrier dans in open channels are of two generd types: (a) a dam which effects a partial closure of a channel, thus concentrating the fresh-water flow into a relatively small cross section and increasing its effectiveness in combating salinity untrusion; and (b) a darn whlcn effects a complete closure of a channel, thus creating a fresil-water pool d an elevation equal to or slightly $\dot{c}$ reater than the salt-water pool downstrean from the basin. wither of these types may be supulemented by locks for navigatiun or auxiliary openings for passage of larğe fresn-water flows. Examples of the former are the barriers proposed for control of salt-water intrusion in the lower Mississippi Hiver, 9 and examples of the latier are the Goolwa Barrage across the lower Goolwa fiver in Australialo and the barrier across the Santa Ynez River at Camp Cooke, California.1l

Several types of movable barriers have been designed for the control of salinity intrusion, and a few of these lave been constructcd and opercuted. A movable tidal gate was constructed across the Wiami River Cana-, Hiami, Florida, and operated for some time to prevent salt-water intrusion into the canal. 12 One-way gates to prevent intrusion of salt water at hlgh tide, at the same time permitting drainage of fresh water at low tide, have been usea successfully in a number of cases. Such gates are usually relatively small and are installed in highway and railroad culverts; however, fairly large gates of this type have been utilized also. Ar example of the larger gates of this type is that used in Skagit County, washungton, which controls drainage from and prevents salt water intrusion into an area of about $600 \mathrm{v}$ acres of highly productive farm land. 13

\section{REDUCTION UF SHOAIING IN TIDAL WATERWAYS}

The problem of flocculation of suspended or dissolved solids by salt water is further complicated by the effects of density currents on 


\section{COASTAL ENGINEERING}

botton velocities in estuaries. It has been pointed out that salt water tends to move upstream because of zts greater density, sometimes underneath the fresn water and sometimes mixed with the fresh water in various degrees, and the net effort of this upstream movement is that bottom velocities in most estuaries are stronger during flood tide than during ebb tide. Surface velocities, on the other hand, are usually considerably stronger during ebb tide than during flood, since it appears that inost of the fresh water run-off is carried to sea in the upper stracas, especially if the estuary is one $\lrcorner n$ which litlle mixing of the fresh and salt water occurs. 'the inportance of such effect on the vertical distribution of currents in an estuary is obvious, since it is extremely difficult for a deposit of material, once formed on the river bed, to be removed by natural forces and carried out to se.2 if the bottom currents moving upstream are normally predominant over the downstream currents. In fact, there is evidence that material flocculated in the lower reaches of some estuaries is trence progressively moved upstream by the predominant botiom currents to form shoals in the upper reaches of the estuary.

The usual plans adopted to reduce shoaling In tidal estuaries consist of proper chanilel alignment, the construction of training works to obtain good flow conditions in the navigation channel, removal of obstructions to the free run of the tide, elimination of channel bifurcation when possiole to eluminate cross flows and eddy action, construction of jetties where reuuired to concentrate flow, etc. It has also been proposed on numerous occasions that the construction of reservoirs in the fresn-water section upstream from the head of an estuary, the revetment of banks to elilinate bank caving and scour, and the dredging of sedimentation basins, either in the estuary proper or in the fresh water section upstream, might be effeclive in reducing the suspended load entering the estuary and therefore reduce the amount of solids available for flocculation by salt water. Sedimentation basins located in the fresh water section would probably be ineffective in reducing the suspended load, however, and the cost of constructing reservoirs and bank revetinent is usually so great as to be prohibitive. Also, there is some evidence that suspended material in appreciable quantities can pass through one or more reservoirs without being deposited, only to be flocculated on coming into contact with the salt water of an estuary and contributing to shoaling of the navigation channels therein.

\section{MODEL STUDIES OF SALIIVITY PROBLLIMS}

Hydraulic models have been used quite successfully during recent years for studies of salinity intrusion problems in open chamels and in locks. Both theory and experience have shown that so long as gravity is the controlling force in the formation and movement of density currents, which is the case except in rare instances, models should be 


\section{SALINITY PROBLEMS}

designed in accorciance with Froude's model laws of similitude, and the salinity scale, model to prototype, should be unity. The reliability of a salinity scale of unity for model studies of salinity intrusion in open channels was recently confirmed by the resulis of an exhaustive study conducted by the National Bureau of Standards under the direction of Dr. Carbis H. Keulegan.

O'Brien and Cherno, in 1934, published the results of a study to determne a model law for use in the design of hydraulic models for the study of salinity problems. ${ }^{14}$ The design criterion arrived at by Messrs. U'srien and Cherno was:

$$
L_{r}=D_{r}^{2.5} S_{r}^{0.5}
$$

This equation was based on the assumptiun that Ineria and friction were the controlling forces in movernent of salinity currents, gravity being considered only insofar as the Lritial velocity was concerned. 'ihis condltion exists only if a relatively small volume of silc water is releascd into a large body of fresn water as, for exanple, a slug of salt water enteriné $c$. fresh water pool as a result of lock operation, and is therefore limited in scope.

It is usually necessary to reproduce salinity currents in estuary models for two reasons. First, some industrles usuall. draw cooling water directly fror estuaries, dnu any change in salinity, caused by changes $\mathrm{un}$ channel dimensions or other nudifications of che estuary, i $\varepsilon^{\prime}$ increase salinaties to or peyona tre danger point. Secona, as stated previously, the action of salinity or aensity currents is such that the vertical uistrioution of currents in any cross section traversed $v_{j}$ a salt-water wed $e$ is appreciably difierent chan would be the case if all fresh water or all salt water was moving in the cross section. l'he upper portion of Fis. 4 shows a plot of surfice ana bottom current velocities obtained in a moael of Savannah Harbor, Georgia, with on:y fresh water in the model. the lower portion shows a plot of velocities at the same points witn sali watr in the model ocean and fresh water being discharg d irto the upstream end of' the model estuary. "I'hese plots reveal the greai differences between surface and botton velocities at an identical point for the two conditiuns nentzuned. I'ne lower plot approximates verJ closely the velocity distribution found in the prototype for tidal and fresh-water flow conditions sinilar to whose reoroduced in the model at the time these measurements weru obtained.

It is obvious that the movement of seciment in Savannan Harbor is affected appreciaoly by density currents, especially in that reach of the harbor in which these ineasurements were made. The observations obtained witn salt water in the model ocean show an appreciable flood or upstream velocity on the bottom in this critical reach, but the ebb or domstrean velocit; is zero. The net effect of this difference in 


\section{COASTAL ENGINEERING}

bottom velocity is that naterial deposited in the narbor because of flocculation or other causes may be moved upstream to form shoals in tne navigation cnannel, but it can not be moved downstream and out to sea except during times of exuremely high fresh water flows. It therefore follows that nost of the material accumulated in critical reaches by this peculiar flow phenomena must be removed by dredging to maintain the desired channel depths.

In 1944-1945 a model study of salinity intrusion in the Calcasieu River, which is located in southwest Louisiana, was made by the Watervays Experiment Station, ana this stuay may be used to illustrate the advantages of using hydraulic models in such investigations. 15 The problem involved was whether or not a proposed deepening of the Calcasieu River Ship channel, between the Gulf of Miexico and the Port of Lake Charles, La., from 30 to $34 \mathrm{ft}$ at WGL would further aggravate an already serious salinity intrusion problem in the Calcasieu River and the Gulf Intracoastal waterway east of the Calcasieu River. Water drawn from these streams, especially from the Intracoastal Waterway east of the Calcasieu kiver, is used for irrigating large areas used for rice cultivation.

One of the initial steps in planning the model study was the obtaining of sufficient and reliable hyaraulic and salinity data upon which the adjustment of the model could be based. fidal heights were obtained by automatic tide-recording gages in the Calcasieu River, Calcasieu Lake, and in the Intracoastal waterway east and west of the Calcasleu River. Measurements of current velocity and salinity were made at six selected stations in the area to be reproduced. Fresh water discharges in the Calcasieu kiver and all tributaries were made daily for the duration of all tidal, velocity, and salinity observations. These data provided an accurate basis for adjustment of hydraulic phenomena and verification of salinity intrusion for the then-existing 30-ft channel.

A comprehensive stuay of salinity intrusion in the Calcasieu river area by means of a hydriulic model required that the model be so designed and constructed that both tidal and salinity currents be reproduced accurately throughout the problem area. Therefore, the model reproduced a portion of the Gulf of Mexico, Calcasieu Pass and Calcasieu Lake, 10 miles of the Lake Charles Deep water Chamul to the west of the Calcasieu, 10 miles of the Gulf Intracoastal waterway to the eist of the Calcasieu, the Calcasieu hiver in its natural state to a point about 5 miles above Lake Charles, and the remaining tidal portions of the Calcasieu hiver, houston Kiver, and English bayou above this point in the form of a labyrinth. Fig. 5.

The model was of the fixed-bed type, all channel and overbank areas being molded in concrete. It was constructed to linear scale ratios, model to prototype, of 1:1000 horizontally and 1:50 vertically. The salinity 


\section{SALINITY PROBLEMS}

scale used in the model was $1: 1$. Observed urototype tides were reproduced in the simulated Gulf of Niexico by means of an electromeclianical tide reproducing apparatus, and the roughness values of the model bed and channels were so adjusted that the observea rise and fall of the tides, and the resultang strength and directions of tidal currents, were reproauced tinroughout the model. 'i'he fresh-water inflows, representing the fresh-water aischarges of the Calcasieu and houston hivers, were introduced into the upstream end of the lodel by means of Van Leer weirs.

The water in the model guif was maintained at the observed prototype salnnity by the addition of common salt. 'the salt was adoed to the water-supply sump in the requirea quantities, and was dissolvea by a circulating sump. Since the water which produced the rise and fall of tne lide in the model circulated through this sump, the water in the model gulf was inaintained at its correct salusity at all times.

Operation of the model for the verification test, and for tests of the various channel conditions for which information was desired, was begun with the river system filled with fresh water and the gulf filled with salt water, the two bodies of water being separated by a movable block located at the lower end of Calcasieu lake. The tide control mechanism was then started and the block was removed, the fresh-water inflow weirs having been adjusted to reproduce the desired inflow for trat particular test.

It is obvious that conditions in any tidal stream in nature represent an adjustment between the forces of fresh-water flow and those of tidal flow. It can be readily understood, therefore, that these forces in the model must be allowed to adjust themselves before a state of stabilization is reached. In the model, where factors affecting the adjustment between the se forces are controlled, as they are not in the prototype, such a state of stabilization is characterized by the repetition of the action of the salt-water wedge during successive cycles of operation. when the position of the weage becomes stable, or the advance and retreat of the wedge with tidal action is constant, the wedge may then be considered to have penetrated as far into the river as it will for the $\infty$ nditions reproduced.

For verification of the Calcasieu Fiver model, the conditions of tidal action, fresh-water inflow, and gulf salinity were reproduced in the nodel in cccordance with prototype data obtained during the field survey of the prototype previously mentioned. After the model was operated through the stabilization period, salinity samples were obtained at all stations and depths corresponding to the stations and depths at which prototype measurements were obtained. The results obtained from the model were then compared to data obtained in the prototype for similar 
COASTAL ENGINEERING

TABLE I

SALINITY MEASUREMENTS -- VERIFICATION TEST

Salinity values are expressed in parts per million

and represent average of all samples obtained during one tidal cycle

\begin{tabular}{|c|c|c|c|}
\hline $\begin{array}{r}\text { Salinity } \\
\text { Station } \\
\end{array}$ & $\begin{array}{c}\text { Depth } \\
\text { Sample Taken }\end{array}$ & $\begin{array}{l}\text { Average Salinity for } \\
\text { Model }\end{array}$ & $\frac{\text { One Tidal Cycle }}{\text { Prototype }}$ \\
\hline $\begin{array}{l}1 \\
1 \\
1\end{array}$ & $\begin{array}{r}0.0 \\
-15.0 \\
-30.0\end{array}$ & $\begin{array}{r}2,360 \\
5,625 \\
14,790\end{array}$ & $\begin{array}{r}3,280 \\
5,290 \\
12,670\end{array}$ \\
\hline $\begin{array}{l}2 \\
2 \\
2\end{array}$ & $\begin{array}{r}0.0 \\
-14.0 \\
-28.0\end{array}$ & $\begin{array}{r}500 \\
500 \\
12,340\end{array}$ & $\begin{array}{r}430 \\
430 \\
9,740\end{array}$ \\
\hline $\begin{array}{l}3 \\
3 \\
3\end{array}$ & $\begin{array}{r}0.0 \\
-16.0 \\
-31.0\end{array}$ & $\begin{array}{r}400 \\
500 \\
14,520\end{array}$ & $\begin{array}{r}330 \\
418 \\
7,150\end{array}$ \\
\hline $\begin{array}{l}4 \\
4 \\
4\end{array}$ & $\begin{array}{r}0.0 \\
-15.0 \\
-30.0\end{array}$ & $\begin{array}{l}75 \\
80 \\
85\end{array}$ & $\begin{array}{l}73 \\
74 \\
76\end{array}$ \\
\hline $\begin{array}{l}5 \\
5 \\
5\end{array}$ & $\begin{array}{r}0.0 \\
-6.0 \\
-12.0\end{array}$ & $\begin{array}{l}400 \\
400 \\
400\end{array}$ & $\begin{array}{l}320 \\
319 \\
322\end{array}$ \\
\hline $\begin{array}{l}6 \\
6 \\
6\end{array}$ & $\begin{array}{r}0.0 \\
-14.0 \\
-27.0\end{array}$ & $\begin{array}{r}700 \\
700 \\
2,000\end{array}$ & $\begin{array}{r}657 \\
669 \\
1,968\end{array}$ \\
\hline
\end{tabular}




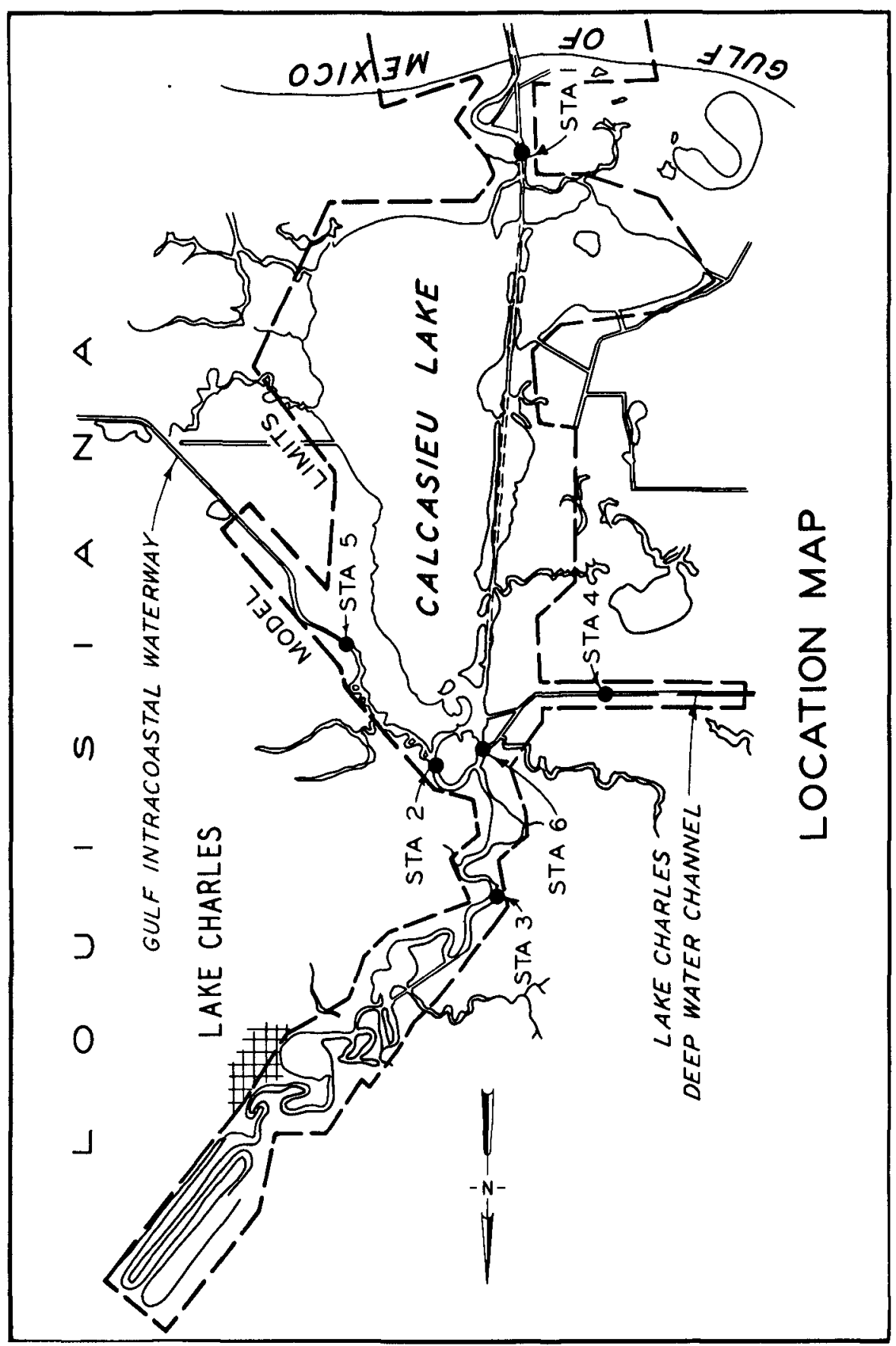

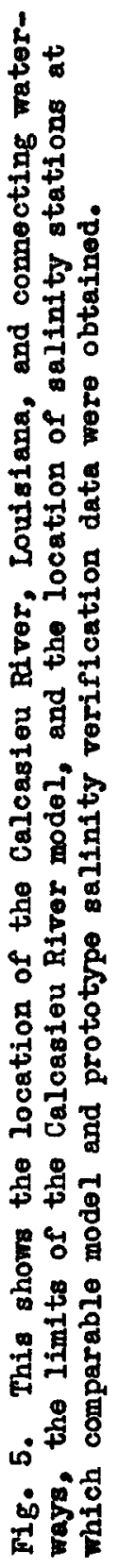




\section{COASTAL ENGINEERING}

conditions (table 1), and it was found that salinities in the model checked those obtainea in the prototype with a remarkable degree of accuracy. The verification test was repeat $\in$ d several times to insure that identical and consistent results would be obtained.

After the verification of the model had been established, extensive salinity measurements wert obtained for a series of fresh water river discharges and a series of eastward and westward flows in the Gulf Intracoastal waterway. These various test conditions were selected with a view toward obtaining salinity data for any combination of flow which might be expected to occur in the prototype. Sufficient data were obtained during each test to serve as a basis for comparison of the results of later tests made after deepening the project channel. After all tests of the existing channel had been completed, the model channel was deepened to the new project and the series of tests was repeated. It was found that deepening the channel had very little effect on salinities in the Calcasieu River or in the Gulf Intracoastal waterway east of the Calcasieu. Slight local differences were noted, usually occurring at middepth of the channel; nowever, there was no apparent overall change in salunities.

Following a thorough analysis of the results of all model tests, it was concludea that the proposed chanr,el deepening would have no adverse effects on salinnty intrusion in the Calcasieu kiver and the Intracoastal Waterway east of the Calcasieu. Since salinity intrusion for the 30-ft channel caused a serious problem at certain tiles, it was further concluded that a guard lock in the waterway should be constructed to alleviate tinis condition. A guard lock was constructed in the Intracoastal waterway near black jayou, and it is the understanding of the writer that this lock has been very successful in preventing contamination of irrigation water therein by the intrusion of salt water from the Calcasieu River.

\section{COHCLUDING REMAHKS}

This paper nas covered only the general aspects of salinity problems and possible solutions, and was prepared to stimulate the thinking of other engineers in this respect rather than to show how salinit problems should be solved. The people of this country, especially the engineers, are constantly devoting more and more thought to water conservation and proper use of waver, and it is the writer's opinion that salinity problems will receive more attention and study as inland sources of water are gradually developed to the fullest extent possible. The day may soon arrive when we, like the Dutch, will find it necessary or profitable to reclain marginal land from the sea by the exclusion of salt water, and in doing so it is inevitable that new and startling engineering solutions will be developed. 


\section{SALINITY PROBLEMS}

\section{FHF DFELVES}

1. U.S., National Resources Planning Board: Regional Planning, Part X, Pecos River Joint Investigation in the Pecos hiver basin in New Mexico and l'exas; Summary, aralysis, Findirgs, 1942.

2. Louisiana, Department of Conservation: Calcasieu Kiver Survey, 1942.

3. Natthes, G.H.: Flocculation of River Clays Mhrougn Contact with Salt Water. New York, N.Y., Deceraber 1948.

4. Hynes, V.M.: Salt Content of wells in Massachusetts Affected by the l'idal Wave and Hurricane of 1938. (New tingland water works Association Journal, 56: 355-360, Sept ember 1942.)

5. Barden,iw.J., and Sargent, A.W.: Irike Washington Ship Canal (Trans., H.S.C.E.., 92: 1001-40.)

6. Waterways Ixperiment Station: Model Studies of Water Requirements and Salt Water Intrusion, Intracoastal Waterway, New York Bay-Delaware River Section. Final heport, 1946.

7. Young, G.K.: The Great Bridge Lock. (Military singineer, Vol. Xxiv, November-December 1932, 138: 551-557.)

8. U.S., Department of the Army, Corps of Ingineers: Definite Project Report, Mermentau River Básin, Mermentau iniver, Louisiana, Flood Control, Irrigation, and Navigation, 1948.

9. U.S., War Department, Corps of kngineers: Salinity, Mississippi River at and Below New Orleans, June 1942.

10. Lawrie, E.K.P.: Construction of the Goolwa Barrage. (iustralian lingineers Journal, Aubust 1940, 12: 221-231.)

11. Beardislee, C.G.: Salt water Barrier at Cooke. (western Construction New 5, 17: 53-55, February 1942.)

12. Wailes - Dove - Hermiston Corporation: Checking the lide Waters of the Everglades. Westfield, 1944. (ITS Bitumastic Eulletin No. 30.)

13. Muecus, F.K.: Skagit Bay 'l'zde Gate hepaired. (western Construction News, 17: 10u-102, August 1945.)

14. U'Brien, M.P., and Cherno, J.: Model Law for Motion of Salt Water through Fresh. (I'rans., A.S.C.i.., 99: 567-609, 1934)

15. Waterways ixperiment Station: Salt-water Intrusion in the Calcasieu River, Louisiana, and Connecting Waterways; Hodel Investigation. Final Report, 1949. 


\section{COASTAL ENGINEERING}

16. barksdale, H.C.: Ground hater Froolens in ive: Jersey. (Journal American water works Association, 34: 563-68, June 1945.)

17. Brenseke, A.1.: Control of Salt water InLrusios, in Texas. (Journal, American Water iorks Association, 37: 579-84, June 1945.)

18. California, Department of Public horks, Division of vater Resources: Economic Aspects of a Salt Tater Barrier below Confluence of Sacramento and San Joaquin Rivers, 1932. (I'l'S Bulletin No. 2s.)

19. California, Department of Public iorks, Division of iater Resources: Keport on Salt water Barrier below Confluence of Sacramento and San Joaquin Rivers, California. Sacramento, 1949. (Il'S Bulietin No. 22.)

20. California, Department of Public Works, Division of water Resources: Variation and Control of Salinity ir Sacramento-San Joacuin Delta and upper San Francisco Bay,1931, Sacramento, 1932. (II's Bulietin No. 27.)

21. California, Department of Public Works, Division of Water Resources: Proposed liajor Development on American River; Analysis of its utility in the coordinated plan for tne development of tre water resources of California, 1930. (I'SS Bulletin ivo. 24.)

22. Eldridge, L'.P.: Industrial Waste 'ireatment fractice, 1942.

23. Fries, F.E., and Viney, A.G.: Hydraulic liodel l'est of Lake Washington Ship Canal; thesıs, 1933. (Engineering News Kecord, June 1933.)

24. Kelley, in.P.: Permissible Composition and Contraction of Irrigation water. (Transactiuns, A.S.C.E., 1941, 106: 849-861.)

25. Parker, G.G.: Salt water Encroachment in Soutnern Florida. (Journal, American irater Works Association, 37: 526-542, June 1945.)

26. Pennsylvania, State Department of Health, Bureau of Engineering: Final keport to the Sanitary Water Boald by the Bureau of Engineering on the Salinity Survey of the Delaware River. Harrisburg, Miay 1935, 2 Vol.

27. Poland, S.F.: Saline Contamination of Coastal water in Southern Californ (viestern City, 19: 46, 48, 50, October 1943.)

28. Riddel, J.U.: Lxcluding Salt water from Island Wells. (Civil engineerin 3: $383-385$, July 1933.) 


\section{SALINITY PROBLEMS}

29. Scofiela, U.s.: weasuring the Saludity of Irrigatiun waters and of soll solutions with the wheatstone sridge. July 1932. (U.b. Department of Aigriculture, circular wo. 232).

30. Service, J.H.: Heasurement of Salinity of bea water, (U.S. Coast Geodetic jurvey, Special Publications No. 147, 1928.)

31. U.S., 'Norks Progress Adninistratiun: Salirity of tre Connecilcui wiver October 1934-September 1937. hartfora, Con.., Uctober 1938-June 1939 3 Vol.

32. water.uys experznent Station: liodel Study of Salt bater fritrusion, Lower ivis'stissipp kiver. Prelirinary ıeport, ivay 1942.

33. Waterways Experiment Station: Plans for whe Improvemunt of the st. Joins Kiver, Jacksonville to the Ocean; kodel Investigition. Final iteport, 1947 .

34. Waterways txperiment Stution: Flans for Improvement of Ivavigation Conditions and ilulination of Snoalin in Savannah H rbor, Georgia, and Cornecting watervays; ilodel Investicution, Final keport, 1949.

35. Wood, H.B.: Saline Condit_ons of the lississippi hiver, Nev Urleans, 1937. 